\title{
MANIFESTAÇÓES DO SAGRADO NO ESTADO LAICO BRASILEIRO PELA PERSPECTIVA DE RONALD DWORKIN
}

\author{
MANIFESTATIONS OF THE SACRED WITHIN THE BRAZILIAN \\ SECULAR STATE FROM THE PERSPECTIVE OF RONALD DWORKIN
}

\author{
Edson Vieira da Silva Filho ${ }^{1}$ (e) \\ Rodrigo Pedroso Barbosa ${ }^{\mathrm{II}}$ (])
}

I Faculdade de Direito do Sul de Minas, Pouso Alegre, MG, Brasil. Doutor em Direito. E-mail: evsilvaf@globo.com

${ }^{\text {II }}$ Faculdade de Direito do Sul de Minas, Pouso Alegre, MG, Brasil. Mestre em Direito. E-mail: evsilvaf@globo.com

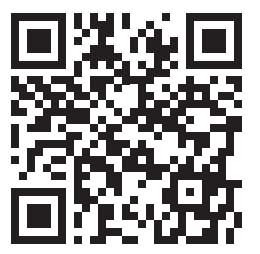

DOI: http://dx.doi.org/10.31512/rdj.v21i39.309

Recebido em: 22.09.2019

Aceito em: 18.07.2020
Resumo: Este artigo busca, através de uma leitura da perspectiva de Ronald Dworkin, compreender o sentido do sagrado e das manifestaçóes iconográficas dentro do Estado brasileiro, autodenominado laico através da Constituição de 1988. Inicialmente, o próprio sentido do sagrado é analisado, concluindo-se que este pode existir tanto no universo religioso como no secular. A origem do sagrado secular é compreendida através do processo de atribuição e associação, que decorre da própria ideia de Estado. Analisa-se, também, partindo de uma análise da decisão do Conselho Nacional de Justiça, a adequação dos argumentos atualmente encontrados para a permissão de símbolos religiosos em espaços públicos brasileiros. Finalmente, utilizando-se dos estudos de Ahmet Kuru, analisam-se modelos de relacionamento Estadoreligião nos Estados Unidos da América, França e Turquia, incluindo a posição de trais atores em relação ao uso de iconografia religiosa nos espaços públicos e privados, e como estas poderia ser aplicadas ao Brasil. Conclui-se pela impossibilidade da importação de teorias alienígenas, pois incompatíveis com o constitucionalismo brasileiro, sendo necessário o desenvolvimento de uma teoria da laicidade adequada ao Brasil. Para o desenvolvimento desta pesquisa, utilizou-se como marco teórico Ronald Dworkin, bem como aporte de diversos autores, destacando-se e Roberto Blancarte Pimentel e Ahmet Kuru. Prestando-se a um diagnóstico, e não conclusão, finaliza-se com uma reconstrução sistêmica dos conceitos basilares para se que possa prosseguir com a discussão sobre o processo de laicização, algo continuo, sujeito a falhas, abusos, avanços e retrocessos, e deve sempre ser monitorado e aprimorado, mas que, para tal, necessita de pontos comuns para discussão e diagnósticos de suas fragilidades, o que se espe-ra germinar com o presente.

Palavras-chave: Laicidade; Laicismo; Secularidade; Direitos Fundamentais. 


\begin{abstract}
This paper aims to, through the theoretical perspective of Ronald Dworkin, to un-derstand the meaning of the sacred, as well as the iconographic manifestations within the Brazilian State, self-described as being secular in the 1988 Constitution. Initially, the mean-ing of the sacred is analyzed, concluding that it can exist both in the religious and secular universes. The origins of the secularsacred is understood through the attribution and associ-ation process, that derived from the idea of the State. We also analyze, using a decision of the Conselho Nacional de Justiça as the basis, the adequacy of the current argument used to allow religious symbols in Brazilian public spaces. Lastly, by means of the studies published by Ahmet Kuru, the different relationship models between state and religion in the United State of America, France and Turkey are analyzed including the position taken by these coun-tries related to the usage of religious iconography in public and private spaces, and how those could be applied to Brazil, concluding it would be impossible to import these alien theo-ries, being incompatible with the Brazilian constitutionalism. It is needed, therefore, to devel-op a theory of laicity adapted to Brazil. This research was developed with Robert Dworkin as the main theoretical reference, as well as inputs from several authors, among those Roberto Blancarte and Ahmet Kuru merit special mention. As a means of a diagnostic, and not a con-clusion, this work closes with a systemic reconstruction of the basic concepts presented, so to begin a discussion on the laicization process as something ongoing, subject to failures, abus-es, advancements and setbacks, and something that requires constant monitoring and im-provements but that, to that end, need an common grounds for discussions and a diagnostic of its frailties, hopefully seeded with this text.
\end{abstract}

Keywords: Laicity; Laicism; Secularity; Fundamental Rights

\title{
1 Consideraçóes iniciais
}

Conceituar laicidade, do ponto de vista do Direito, não é tarefa trivial. Diversos autores (e.g. Roberto Blancarte) tentaram, com variados graus de sucesso. A dificuldade muito anteceda à própria palavra, pois até mesmo conceituar religião, o que é e o que não é, é tarefa complexa (BARBOSA, 2020, p. 38-49). O próprio sentido da laicidade pode ser explorado por diversas vertentes, desde o sentido mais básico, de dicionários, até por uma leitura hermenêutica da laicidade do Brasil contemporâneo.

Dentro de um estudo sobre religião, no geral, e laicidade, em particular, o conceito do sagrado não tarda a surgir. O atual Código Penal (BRASIL, 1940) prevê a conduta de vilipendiar publicamente objeto de culto como criminosa, em seu artigo 208. Tal objeto seria sagrado, dentro de uma (de várias) definiçóes do dicionário Michaellis (2017), que conceitua sagrado como algo 
que não se deve infringir, inviolável. Ou, enquanto substantivo masculino, algo consagrado para cerimônias de culto, vedada a profanação. Ponta o dicionário, ainda, o antônimo como profano.

Tem-se desde logo uma simples (simplista) definição do profano, como o oposto do sagrado. Portanto, para se definir o profano é imprescindível definir o sagrado. E se o sagrado é uma virtude positiva, o profano é uma negativa, não se olvidando a possibilidade do neutro (nem sagrado, nem profano). A tarefa passa, entáo, a ser a compreensão do sagrado. Tal compreensão não é trivial; em particular para o Direito. O sagrado não é um conceito positivado.

Sagrado é algo que merece respeito profundo e veneração absoluta. Não apenas no conceito religioso, ainda que obviamente aplicável, mas além. Venera-se e se presta o mais profundo respeito à bandeira nacional. O sagrado é religioso e não é religioso. $\mathrm{Ou}$, não religioso, que se veste de contornos normalmente associados à prática religiosa, mesmo dentro de um contexto secular.

Busca-se, assim, melhor compreender o sagrado e, como decorrência, o profano, dentro de uma perspectiva do Direito brasileiro, utilizando-se do referencial teórico de Ronald Dworkin, o método de pesquisa bibliográfica, e com aportes da obra de Roberto Blancarte Pimentel. São ainda utilizados referenciais nacionais e internacionais compatíveis com o marco selecionado e apropriados à realidade latino-americana, em geral, e brasileira, em específico.

\section{A ontologia do sagrado}

O músico, compositor, diretor e ganhador de diversos prêmios Tony e Grammy, Tim Minchin $^{1}$, em um concerto no The Royal Albert Hall, Inglaterra, em 2011, durante breve interlúdio, sentado ao piano, aborda a questão do sagrado, inspirado por um fato ocorrido, então há pouco, em que um americano divulgou na Internet sua intenção de queimar cópias do Corão, livro sagrado dos muçulmanos.

Inicialmente, retira de sua bolsa e deposita sobre o piano a cópia de um livro, de capa verde, letras douradas, com o título "The Holy Qur'än”, questionando sobre o que faz tal objeto sagrado. Jocosamente, pergunta, ao mesmo tempo, o que faz com que 4000 mil pessoas (na plateia) tivessem quase que instantaneamente ficado nervosas. Em seguida, colocando outro livro sobre o piano, questiona sobre o que torna o livro sagrado diferente da cópia de "Harry Poter e as Relíquia da Morte" colocada, agora, ao lado do livro anterior. E sim, reconhece que são diferentes quanto ao sagrado.

Tim Minchin parte então para tentar definir qual seria esta diferença. Seriam as palavras? Mas, desde a invenção da prensa móvel, as palavras do livro sagrado do Islá foram reproduzidas centenas de milhóes de vezes. Felizmente, afirma, estas palavras antigas são indestrutíveis. Então não pode ser isso. Talvez, questiona, seja a estética. Talvez julgar o sagrado de um livro por sua

1 O episódio narrado está disponível no DVD "Tim Minchin and the Heritage Orchestra”, gravado ao vivo no The Royal Abert Hall, Londres, em 2011. 
capa? Talvez a mera presença da palavra "Qur’än"? Se alguém, entretanto, utilizar o livro a tal ponto que este se desgaste, que suas letras comecem a desaparecer, isso o tornaria menos sagrado?

E, questiona o músico, sendo o sagrado ligado à palavra "Qur'än” (o mesmo tempo fazendo o que narra), o que aconteceria se ele colasse uma nota adesiva com tal palavra na capa da cópia do livro "Harry Poter e as Relíquias da Morte", isto o tornaria mais sagrado? Finalmente, questiona o que aconteceria se ele retirasse a capa escrita "Qur'än" de uma cópia de "Harry Poter e as Relíquias da Morte" (que era, na verdade, o primeiro livro exibido, apenas com uma capa impressa diferente) e colocasse sobra a outra. Removendo as duas cópias da "Harry Poter e as Relíquias da Morte”, restando apenas a capa, vazia, com os dizeres "Qur’än”, qual o atributo de sagrado restante?

Conclui, finalmente, reafirmando o direito de as pessoas atribuírem e definirem o que é sagrado para cada um, contanto que não forcem que outras pessoas também considerem estes objetos como sagrados. Que impedir que outros critiquem ou comentem sobre coisas ou pessoas, consideradas sagradas, os coloca acima de qualquer crítica e, assim, conforme o músico, inexoravelmente caminha-se para a corrupção ${ }^{2}$.

A abordagem artística, cômica e descontraída do músico não deixa de carregar certa profundidade, quando desconecta a ideia do sagrado de um conceito ontológico, localizado no objeto, passando a localizá-lo como uma característica definida unicamente pelo sujeito ${ }^{3}$.

Dworkin aborda a questão do sagrado. Para o autor, coisas intrinsicamente valiosas se dividem em duas categorias.

Porém, não basta apenas dizer que a idéia de valor intrínseco nos é familiar. Afinal, o que nos interessa aqui é uma aplicação especial dessa idéia - a afirmação de que a vida humana, mesmo em sua forma mais incipiente, possui valor intrínseco -, e essa aplicação levanta problemas inusitados. Por que dessa idéia não se segue, por exemplo, que deveria haver tanta vida humana quanto possível? A maioria de nós certamente não acredita nisso. Ao contrário, seria melhor, ao menos em muitas partes do mundo, que houvesse menos vida humana, não mais. Então, como pode ser intrinsecamente importante que a vida humana, uma vez começada, continue a existir? São pergunta importantes, e ao responde-las descobriremos uma distinção entre duas categorias de coisas intrinsecamente valiosas: as que são incrementalmente valiosas - quanto mais tivermos, melhor - e as que não são, mas que possuem valor em um sentido muito diverso. Chamarei estas últimas de valores sagrados ou invioláveis (DWORKIN, 2009, p. 97).

O valor intrínseco incremental não deve ser confundindo com apenas relacionado com a existência, só valorizado quando já existe. Usa-se, como exemplo, o conhecimento.

2 Tim Minchin aqui aborda a questão dos escândalos de pedofilia na Igreja Católica. Tim Minchin é conhecido mundialmente por criticar as religióes e, ao mesmo tempo, defender o direito à liberdade religiosa, contra preconceito e discriminação.

3 A atribuição de sentido pela vontade do sujeito é particular da filosofia da consciência, que é incompatível com a hermenêutica filosófica de Dworkin. Seria o sujeito "assujeitando" o objeto, a ele impondo o sentido que brota (unicamente) de sua consciência (relação sujeito-objeto). É uma visão diametralmente oposta à ideia de que o sagrado estaria na essência do objeto, extraída pelo sujeito que o conhece (relação objeto-sujeito). 
Independentemente de qualquer quantidade, o conhecimento é, em si, valioso. Quanto mais conhecimento, melhor, ainda que sobre coisas que podem jamais ser de utilidade prática, como fatos sobre galáxias a milhôes de anos-luz de distância (DWORKIN, 2009, p. 102).

Já o sagrado, para Dworkin, para ser intrinsecamente valioso, somente o é a partir do momento que exista, com sua inviolabilidade decorrendo do que representa ou incorpora. Este valor vai muito além do sentimento religioso, e pode ser encontrado em outras áreas, como em obras de arte, conquanto existam. Ainda que não importe se mais serão criadas, é horrorizante (profano) se uma for destruída. "Uma coisa é sagrada ou inviolável quando sua destruição deliberada desonra o que deve ser honrado” (DWORKIN, 2009, p. 102-103)

Para Dworkin, o sagrado, apesar de representar um valor inerente, não é uma propriedade inerente. Não é algo já pré-existente, só sendo possível após a existência da coisa. É algo atribuído, algo alcançado. Algo se torna sagrado. Este processo pode acontecer de duas formas distintas.

A primeira forma é por associação ou designação (DWORKIN, 2009, p. 103). Um objeto de culto é sagrado por sua associação com a religiāo. Para os egípcios antigos, o gato era sagrado por sua associação com uma determinada deusa. A cruz cristã é sagrada não por sua natureza original, como instrumento de morte e tortura, mas por sua associação com seu maior ícone religioso.

Mas o processo de se tornar sagrado por associação ou designação não para na esfera do religioso, se entendendo a elementos culturais e até mesmo parte do Estado. Os símbolos nacionais são sagrados para muitas culturas, inclusive no Brasil. A título de exemplo, a proibição de desrespeito à Bandeira Nacional, a obrigatoriedade não apenas a execução integral do Hino Nacional em diversos eventos e locais (algo não necessariamente vinculado à ideia de sagrado), mas a obrigatoriedade de que todos devem ficar em pé e em silêncio, inclusive com os homens (exclusivamente) devendo permanecer com a cabeça descoberta (BRASIL, 1971). O processo em que esses se tornam sagrados por associação é facilmente identificável, sendo os símbolos da República Federativa do Brasil (BRASIL, 1988). Ou, em outras palavras, são sagrados por serem associados à República, e não por uma valoração incremental (DWORKIN, 2009, p. 103).

A segunda forma é devido à história da coisa:

O segundo processo mediante o qual uma coisa pode tornar-se sagrada é a sua história, o modo como veio a existir. No caso da arte, por exemplo, a inviolabilidade não se estabelece por associação, mas por sua gênese: o que confere valor a uma pintura não é o que ela simboliza nem aquilo a que está associada, mas o modo como veio a existir. Protegemos até mesmo uma tela que não apreciamos muito, assim como tentamos preservar culturas pelas quais não temos nenhuma admiração especial, pois elas corporificam processos de criação humana que consideramos importantes e admiráveis (DWORKIN, 2009, p. 104).

O processo de caracterização do sagrado por sua história também é facilmente observado no Brasil, com a proteção e preservação ao patrimônio histórico. Não se inclui, necessariamente, o patrimônio cultural e artístico, pois esses podem ser sagrados por associação ou designação, 
assim como por sua história. Não obstante, tal proteção aparece como mandado constitucional, em não menos que 3 diferentes artigos da Constituição de 1988, com clara indicação de seu valor intrínseco (e não instrumental) e, assim, características de sagrado.

A proteção do sagrado-religioso também encontra previsão no ordenamento pátrio, especialmente na forma do artigo 208 do Código Penal, já mencionado. Ao passo que as duas primeiras condutas estão vinculadas à proteção de liberdades individuais, respectivamente a liberdade de crença e a liberdade de (prática de) culto, observa-se na conduta de "vilipendiar publicamente ato ou objeto de culto religioso" uma proteção não da liberdade do indivíduo, mas sim do sentimento religioso, do sagrado.

É inevitável a comparação ao crime de blasfêmia (injúria religiosa), como previsto no Brasil, no Livro V das Ordenaçôes Filipinas (BRASIL. Senado Federal, 2017), que vigorou mesmo após a Independência e até o advento do Código Criminal de 1830. Por sua vez, o Código de 1830 (BRASIL, 1830) criminalizava o simples fato de se divulgar doutrinas contrárias a religiáo oficial do Estado.

Nas lições de Nelson Hungria:

A terceira modalidade de crime lasa religionis prevista no Código é a constante na parte final do art. 208: "vilipendiar publicamente ato ou objeto de culto religioso". É uma das formas do antigo sacrilegium, embora secularizada. Vilipêndio (de vilis pendere) é o ultraje, o ludíbrio aviltante, o desdém injurioso. Pode consistir em palavras (injúrias verbais), atos (escarrar, stercora projicere, etc.) ou escritos (afixação de cartazes deprimentes). É um requisito essencial, também aqui, que o fato seja praticado publicamente, isto é, se o agente penetra, por exemplo, numa igreja e, sem testemunhas, conspurca uma imagem. Só se apresenta o vilipêndio quando feito diretamente sobre o objeto ou junto deste, ou durante a celebração ou realização do ato. Não importa o local do vilipêndio: se dentro ou fora do templo, em lugar público ou privado (posto que corram multis personis) (HUNGRIA, 1981, p. 64-64).

Porém, alerta Hungria, a definição de objeto de culto deve ser melhor pormenorizada:

Objeto de culto é qualquer das coisas corporais inerentes ao serviço do culto, e não somente aquelas que são, em si mesmas, objetos de veneração religiosa (imagens, relíquias). Assim, são objetos que servem necessariamente à manifestação externa de culto (e, portanto, compreendidos no texto legal): altares, batistérios, oratórios (mesmo os particulares), água-benta, aspersórios, turíbulos, paramentos eclesiásticos, livros litúrgicos do templo, exemplar da Bíblia usado na igreja evangélica, púlpitos, etc. É preciso que tais objetos estejam consagrados ao culto: não serão especialmente protegidos quando, por exemplo, ainda exposto à venda numa casa comercial HUNGRIA, 1981, p. 65).

A mesma posição adota, mais recentemente, Bitencourt (2012), ao afirmar que

objeto de culto religioso são todos aqueles que servem para a celebração desses atos, tais como altar, púlpito, paramentos, turíbulos etc. Estáo excluídos da tipificação aqueles objetos que não integram a essência do culto propriamente dito, como bancos, instrumentos musicais, luminárias, entre outros. Finalmente, é necessário que os objetos 
do culto estejam destinados ao culto, pois, se se encontrarem expostos à venda, náo tipificarão o crime.

Essa posição, não é, entretanto, compartilhada por todos. Paulo Busato (2017) afirma que:

A interpretação ampla segue opinião antes vazada por Magalhães Noronha, que afirmava que poderiam ser objetos aqueles que servem de suporte ao exercício da religião, independentemente de terem qualquer consagração. Pode ser objeto de culto tudo aquilo que poderá ser destinado para os fins do culto, como imagens, sinos, cruzes etc.

A segunda posição parece mais correta, uma vez que o que se pretende proteger é a liberdade religiosa.

Um verdadeiro Estado laico, que pretenda proteger a liberdade de culto como tal, deve compreender que a religiáo possui nuances que chegam quase à individualidade, admitindo-se, como manifestação legítima a criação de relação espiritual com qualquer liturgia ou objeto. Não obstante, é certo que este tipo poderia configurar mera ofensa à honra subjetiva.

Com base na leitura dworkiana, ousa-se discordar. A liberdade de culto está tutelada na segunda conduta tipificada no artigo 208, que seja "impedir ou perturbar cerimônia ou prática de culto religioso", e a liberdade religiosa na primeira e segunda condutas. O vilipêndio de objetos em nada afeta tais liberdades e, embora ofensivo, em nada as impede. A vedação ao vilipêndio de objetos está ligada à ideia do sagrado, do inviolável, como aponta Dworkin, e assim deriva da associação ou designação.

Objetos sagrados para uma religião podem ser profanos para outros. Imagens são sagradas ao cristianismo e proibidas no islamismo. Para um muçulmano, destruir uma imagem é um ato de fé, ao passo que um cristão, ao se macular uma imagem, está cometendo um ato de violação. Pode um muçulmano ser condenado, nos termos do artigo 208 do Código Penal, por destruir uma imagem de uma figura santa cristá, comprada em uma loja e jamais utilizada para práticas religiosas? Tal interpretação seria inaceitável para Dworkin (se não por outros motivos, por violar a própria liberdade dos muçulmanos e não-cristãos), e justifica facilmente as posiçôes de Hungria e Bitencourt.

Assim, a proteção especial ao objeto sagrado só poderia existir a partir do momento em que o processo de designação ocorresse. Do momento em que aquele objeto, específico e individualizado, passasse a integrar as práticas religiosas. Aquele exato objeto integra o culto. Um objeto individualizado, e não uma classe ou categoria. Neste caso a sua violação, seu vilipêndio, atentaria contra a liberdade de crença e de culto. Fosse outra forma, criminalizaria-se a blasfêmia. Um Estado Laico não pode proteger a religião-ente, mas sim a liberdade de crença e culto. Dos indivíduos terem, exercerem e praticarem suas religióes.

Importante destacar que da mesma forma que um objeto, isoladamente, não poderia ser sustentáculo para o crime de vilipêndio, estando ausente uma essência do sagrado no próprio objeto, o processo de designação não é apenas um assujeitamento do objeto pois, caso fosse, a 
proteção perderia qualquer propósito. A designação ocorre para além da simples imposição da consciência sobre o objeto, e é uma construção histórico-social, dentro da tradição hermenêutica em que Dworkin se funda.

\section{Iconografia religiosa e secular nos espaços públicos}

O Estado reconhece, oficialmente, sua própria iconografia: na bandeira, armas e selo nacionais que, juntos com o hino, englobam os símbolos da República Federativa do Brasil, nos termos do $\$ 1^{\circ}$ do artigo 13 da Constituiçấo Federal, bem como no artigo $1^{\circ}$ da lei 5.700/1971 (BRASIL, 1971). Estes símbolos, na concepção de Dworkin, possuem o atributo do sagrado (não-religioso), dignos de proteção, tanto pela designação explícita como por associação com a própria ideia da República.

Observa-se um processo de criação do sagrado que foge à esfera do religioso. Um sagradosecular $^{4}$, mas não menos sagrado por isso. Algo que é inviolável pois "sua destruição deliberada desonra o que deve ser honrado" (DWORKIN, 2009, p. 103), de tal forma que seu desrespeito é punível como contravenção penal ${ }^{5}$. Sua forma e apresentação, descritos em lei, seguem uma ritualística quase eclesiástica. "A Bandeira Nacional pode ser usada em tôdas as manifestaçóes do sentimento patriótico dos brasileiros, de caráter oficial ou particular", reza o artigo 10 da lei 5.700/1971. No artigo $12, \$ 2^{\circ}$, positivam-se os dizeres para a base do mastro especial: "Sob a guarda do povo brasileiro, nesta Praça dos Três Podêres, a Bandeira sempre no alto. - visão permanente da Pátria.”. A ritualista associada, o sentimento do sagrado, do dever de se honrar, chega até mesmo a especificar quais formas de saudação à bandeira são permitidos e quais são vedadas.

O sagrado é, no Brasil e no mundo, inseparável da ideia do Estado, e isto se reflete em sua iconografia. Porém, trata-se do sagrado-secular. Além deste, o sagrado-religioso também, muitas vezes, se fará presente.

Pode-se concluir, desde já, que, vez que a iconografia sagrado-secular do próprio Estado faz parte integral desse, qualquer tentativa de separá-los, ou impedir seu uso, resultaria em uma violação da própria ideia do Estado (enquanto ente) e, assim, não tem relevância direta com a ideia de laicidade ou de um processo de secularização. Ou, se o tem, é algo que o beneficia, pois pode representar uma substituição de ícones. Ao passo que um Estado pode ostentar entre sua iconografia símbolos religiosos, isto seria empiricamente uma violação à ideia de laicidade,

4 Dworkin, em sua definição do sagrado, não o diferencia quanto a sua origem associativa. Porém, para uma análise da laicidade ou secularidade do Estado, essa diferenciação se faz necessária. Assim, adota-se a nomenclatura "sagrado-secular" e "sagrado-religioso" significando o sagrado por associação ou designação, respectivamente, de origem não religiosa e origem religiosa. No mais, esta nomenclatura implica na definição do sagrado apresentada por Dworkin nos seus demais aspectos.

5 Artigo 35 da Lei 5.700/1971: "A violação de qualquer disposição desta Lei, excluídos os casos previstos no art. 44 do Decreto-lei no 898, de 29 de setembro de 1969, é considerada contravenção, sujeito o infrator à pena de multa de uma a quatro vezes o maior valor de referência vigente no País, elevada ao dobro nos casos de reincidência.". 
como aponta Blancarte, entre seus critérios de medição de laicidade, no item 1.3: referência a elementos religiosos entre os símbolos da pátria (BLANCARTE, 2012, p. 240).

O uso de iconografia religiosa, por outro lado, não é de tão fácil análise. Primeiramente, não há vedação expressa, seja na Constituição, seja na legislação infraconstitucional. Não há, em uma análise exegética, violação do dispositivo do artigo 19, inciso I, da Constituição (BRASIL, 1988). O problema é ainda mais agravado quando certos símbolos não são associados a uma única religião, ou mesmo a um único grupo de religióes. Dadas as características de miscigenação e diversidade cultural ${ }^{6}$, uma cruz pode estar associada não apenas a religiôes de matriz cristá, mas também a várias religióes de matrizes diversas, como africanas ou o espiritismo. Observa-se que a vedação constante no artigo 19 não é quanto a religiôes, mas sim a cultos e igrejas e, sendo um símbolo compartilhado por várias, a caracterização de violação constitucional se faz, no mínimo, complexa.

O exemplo do uso do crucifixo não é gratuito ou arbitrário. A questão foi apreciada pelo Conselho Nacional de Justiça (CNJ), nos Pedidos de Providência números 1344, 1345, 1246 e 1362. Para o pedido 1344 (BRASIL. Conselho Nacional de Justiça, 2007), aos quais os demais foram apensados, lê a ementa:

Pedido de providências visando a retirada de crucifixos afixados nos plenários e salas dos Tribunais de Justiça do Ceará, Minas Gerais, Santa Catarina e do TRF-4a região, alegando:

a) que a aposição de símbolo religioso em órgão público fere o art. 19, inciso I, da CF - princípio do Estado laico;

b) que os símbolos religiosos, em alguns tribunais, estão em local proeminente, de ampla visibilidade, acima da própria bandeira nacional, não compondo decoração acidental, mas sim, sugerindo enfaticamente que paira acima dos símbolos e valores oficiais;

c) que a ostentação de símbolos religiosos sugere que os servidores estão submetidos a outros princípios que não aqueles que regem a administração pública;

d) que a iniciativa tomada pelo requerente é apoiada por representantes de um amplo espectro da sociedade, em movimento não sectarista, que visa promover valores importantes de cidadania e da convivência democrática. Pedido Julgado Improcedente.

Os pedidos foram julgados improcedentes, vencido o relator que requeria a instalaçáo de audiência pública. Os argumentos invocados no voto divergente e vencedor, do conselheiro Oscar Argollo (BRASIL. Conselho Nacional de Justiça, 2007), foram de que se trata de símbolos presentes na cultura e tradição, que a tradição da sociedade respeita e não contesta. Ainda, que não viola o interesse público primário, pois garante interesses individuais culturalmente solidificados. Finalmente, que

6 Sobre a questão do sincretismo, mistura e hibridização de religióes no Brasil e na América Latina, ver: BARBOSA (2020, p. 100-102) 
[...] não há, data venia, no ordenamento jurídico pátrio qualquer proibição para o uso de qualquer símbolo religioso em qualquer ambiente de órgáo do Poder Judiciário, sendo da tradição brasileira a ostentaçáo eventual, sem que, com isso, se observe repúdio da sociedade, que consagra um costume ou comportamento como aceitável (BRASIL. Conselho Nacional de Justiça, 2007).

Segue ainda o conselheiro, em seu voto, a caracterizar a importância dos costumes como fonte do direito, afirmando, finalmente, que:

O costume de expor, eventualmente, em dependências ou ambiente de órgão público a imagem de um crucifixo corresponde, sem embargos, a uma necessidade jurídica, de acordo com as homenagens devidas a Justiça. Trata-se de representação, ainda que religiosa, do respeito devido aquele local. O crucifixo é um símbolo que homenageia princípios éticos e representa, especialmente, a paz (BRASIL. Conselho Nacional de Justiça, 2007).

Esta posição é, em uma leitura dworkiana, no mínimo equivocada, além de deveras preocupante. Enquanto possa-se alegar que a mera exposição do símbolo, não vedada, não representa uma atitude de dependência ou aliança, esta ligação fica clara no voto citado, quando fala de "homenagens devidas" e que representam "o respeito devido ao local", atribuindo ao ícone religioso um significado ausente da sua característica sagrada que, conforme Dworkin, origina da sua associaçáo à religião e tão somente a esta, assim como, no Egito antigo, os gatos eram sagrados por sua associação à uma deusa. Se o símbolo religioso está associado ao devido respeito àquele local, decorre que este devido respeito é dado pela religião atribui o caráter sagrado ao símbolo.

Sobre a questão de ser um costume consolidado, tal argumento também não pode ser aceito. Como ensina Jónatas Machado (2002, p. 154), esse argumento carece de legitimidade:

A posição sociologicamente dominante da Igreja Católica alcançada no passado através de um estatuto jurídico e político privilegiado não pode servir no presente para defender a perpetuação de um estatuto jurídico e político privilegiado. Como refere, mais uma vez, Cass Sunstein as regras e as práticas sociais não podem justificar-se a partir das práticas sociais que elas mesmas produziram. Nas suas palavras, um sistema jurídico que produziu preferências através da injusta limitação das oportunidades dificilmente poderá justificar-se por referência às preferências existentes.

Este poder de influência, oriundo da posição historicamente dominante da Igreja Católica seria, para Dworkin (2005, p. 79), uma violaçáo da igualdade. A questáo da influência é definida como "o que pode fazer não apenas sozinho, mas também ao comandar ou induzir outras pessoas a acreditar, votar ou escolher o mesmo que ele" (DWORKIN, 2005, p. 263). Por corolário, se há tratamento desigual, favorecido, à uma determinada religião pelo Estado, esse está, ainda que indiretamente, no mínimo em uma relação de aliança, se não dependência e, assim, violando o mandado constitucional de laicidade. 
Ainda que se desconsidere o poder de influência histórico e o problema apontado por Machado, para Dworkin a decisão do CNJ estaria errada, por carecer de integridade. Nas liçôes de SIMIONI (2014, p. 383):

A concepção de integridade, contudo, possibilita um equilíbrio dinâmico entre previsibilidade do direito e flexibilidade. $\mathrm{O}$ direito como integridade sugere que a prática das decisóes jurídicas é uma prática interpretativa. E que por isso, a interpretação combina elementos que estão orientados tanto para o passado da lei, quanto para o futuro das consequências da decisão.

$\mathrm{O}$ voto do conselheiro do $\mathrm{CNJ}$ está unicamente vinculado ao passado, em uma concepção convencionalista. Fundamenta na existência de vedação legal expressa e nos costumes e tradições, ignorando totalmente elementos do futuro (como a laicidade como princípio da moralidade política representada pela Constituição), e assim negligenciando a decisão no presente. A inexistência de uma vedação legal, de uma regra clara, não pode ser impedimento.

A concepção convencionalista não pode ser aceita nesse caso. Conforme afirma Dworkin, essa se adequa a pessoas que estejam cada uma tentando avançar suas concepçóes pessoais de justiça e igualdade, em detrimento da negociação e transigência, sujeito apenas a um modelo de livro de regras, até que esse seja alterado (DWORKIN, 1986, p. 210). O modelo estabelecido pela concepção convencionalista deixa pessoas livres para agir avançando seus próprios interesses (DWORKIN, 1986, p. 212), ou interesses que suportem; algo especialmente preocupante quando se observa o poder de influência de origem religiosa. No voto, o conselheiro afirma que "[...] não podemos ignorar a manifestação cultural da religiáo nas tradiçôes brasileiras, que hoje não representa qualquer submissão ao Poder clerical” (BRASIL. Conselho Nacional de Justiça, 2007). O que é patentemente falso, conforme já indicado. O restante do voto não é menos eivado de outras falhas, inclusive históricas, mas que, para uma análise detalhada, justificariam um objeto completo de pesquisa, e excessivo para o presente.

Outrossim, para Dworkin, essa seria exatamente a definição de um caso difícil (DWORKIN, 2007, p. 127). Assim, é necessário também abranger questóes de princípio já que, se tratando de uma sociedade moralmente plural, o modelo de associação baseada em princípios é o mais adequado, o que melhor permite interpretar o que se tem de valor, "pois os princípios mantêm a coerência entre a diversidade de opinióes e de expectativas decorrentes das convicçôes morais pessoais" (SIMIONI, 2014, p. 376-377).

Reconhecida a liberdade de crença, qual seria, então, a solução? A eliminação total de restriçôes de manifestaçôes iconográficas religiosas nos espaços públicos do Estado salta aos olhos, vez que é efetivamente impossível oferecer igualdade de representação a todos. Como já indicado, existem mais de 10000 religiôes pelo mundo, com extensa iconografia e, frequentemente, conflitos, onde o sagrado de um é o profano do outro. Estritamente falando, a presença de um crucifixo cristão viola proibição da religião muçulmana. Não sendo possível representar igualmente todos, e nem ainda o fazê-lo de maneira respeitosa (honrada, devido ao sagrado, sem violá-lo), resta como obvio sua exclusão. 
A manutenção de símbolos religiosos em espaços públicos do Estado não garante a liberdade de crença mas a agride, reforçando ainda mais o protagonismo, o poder de influência, de certas religióes ou grupos religiosos, como uma ferida aberta para todos verem, enquanto insistem que o rei está vestido, e que não há um homem detrás das cortinas.

\section{Proteçáo da liberdade religiosa e participaçáo}

A caracterização da liberdade religiosa, de crença e culto, como direito fundamental não apresenta dificuldade. Se encontra, de plano, no título dos direitos e garantias fundamentais da Constituição (BRASIL, 1988), diretamente no inciso VI do artigo $5^{\circ}$. Se encontra também no Artigo 18 da Declaração Universal dos Direitos Humanos (BRASIL. Universidade de São Paulo, 2017) e no artigo 12 Convenção Americana de Direitos Humanos (BRASIL, 1992).

Sobre o tema e a diferença, das liçóes de Bernardo Gonçalves Fernandes:

A liberdade de crença é o direito de um indivíduo adotar ou não uma religião sem ser prejudicado (inclusive o de não adotar nenhuma religião). [...] A liberdade de crença diferencia-se da liberdade de culto. Esse é o direito, individual ou coletivo, de praticar atos externos de louvação próprios de uma determinada religião (e das suas liturgias).

Entendemos que o termo "liberdade de crença" nos parece mais acertado do que a expressão "liberdade religiosa", uma vez que o ateísmo representa uma opção a ser respeitada e protegida pelo Estado (art. 5, VI, da CR/88) (FERNANDES, 2017, p. 444-445).

O doutrinador também aponta que outros autores divergem quanto à classificação, com Canotilho colocando a liberdade religiosa como gênero, com as espécies de liberdade de consciência, liberdade de crença e liberdade de culto.

Não obstante a classificação e separação entre liberdade religiosa, de crença e/ou de culto, a sua ideia (princípio, valor), junto com o conceito de dignidade da pessoa humana, carrega em si a noção do sagrado, do inviolável. Talvez uma das formas mais amplas do sagrado, vez que sua conceptualizaçáo como tal pode ser observada tanto pelo processo histórico, como pelo associativo e por designação. Estão inexoravelmente ligados ao próprio conceito de liberdade, em seu sentido mais amplo, tornando a liberdade religiosa também um sagrado-secular (DWORKIN, 2009, p. 95-113 passim).

Tem-se, consequentemente, uma tensão entre limites e separaçôes. Se o papel da religião no Estado é caracterizado dentro do estudo da laicidade, o papel do Estado na (e para) a religião é menos nítido. Pode se começar, primeiramente, apontando o que não é.

Ahmet Kuru explora a questáo das relaçóes básicas Estado/Religiáo, citando 4 classificaçóes: Estado Religioso, Estado com uma Religião Estabelecida, Estado Secular e Estado Antirreligioso. Esta classificação baseia-se em 2 critérios: o funcionamento do legislativo e judiciário, e a atitude do Estado em relação a religiốes (KURU, 2007, p. 569). Ou, nas palavras do autor, o processo 
legal e judicial está fora do controle institucional religioso, e não estabelecem nem uma religião oficial nem o ateísmo (KURU, 2007, p. 569).

Quanto ao primeiro critério somente no Estado Religioso ocorre uma discrepância, com a legislaçáo e o sistema de justiça sendo baseado em religião. Contam-se 10 tais Estados no mundo, entre eles o Vaticano, Irã e Arábia Saudita e, como corolário inevitável, a atitude do Estado em relação a religióes é de que favorece unicamente uma (KURU, 2007, p. 570).

As demais três classificaçôes de Estados são, quanto a legislação e judiciário, seculares, variando quanto à atitude. No Estado com uma Religiáo Estabelecida, assim como o Estado Religioso, o Estado oficialmente favorece uma religião. Individualmente considerado, esta é a classificação com o maior número de Estados, 100 no mundo, incluindo Grécia, Dinamarca e Inglaterra. No extremo oposto do Estado Religioso está o Estado Antirreligioso, em que o Estado, secular, é oficialmente hostil a todas ou à maioria das religiôes. Contam-se 22 Estados nessa classificação, entre eles a China, a Coréia do Norte e Cuba (KURU, 2007, p. 570).

A última classificação é a do Estado Secular, que oficialmente não favorece nenhuma religião (KURU, 2007, p. 570). Contam-se 95 Estados, entre eles os Estados Unidos da América, França, Turquia e, conclui-se sem maiores dificuldades, o Brasil. Entretanto, como observa-se, essa classificação é bastante restrita, e as políticas e atitudes do Estado quanto a secularidade não é uniforme, de onde Ahmet Kuru virá a classificar como Secularidade Passiva e Secularidade Assertiva (KURU, 2007, passim).

Limitando-se em sua análise, o autor foca nos Estados Unidos, França e Turquia, mais especificamente no debate sobre religiáo nas escolas e a posição de cada um dos três países nos quesitos de proibição do uso de símbolos religiosos por estudantes em escolas públicas (permitido somente nos EUA), juramento recitado em escolas públicas fazendo referência à deus (somente nos EUA), proibição da educação religiosa privada (somente Turquia, onde o Estado busca manter controle da religião), instrução religiosa em escolas públicas (novamente, Turquia), financiamento estatal de escolas privadas religiosa (só existente na França), e a vedação de oraçôes organizadas em escolas públicas (vedado nos três países). Ademais, destaca ainda os dizeres "In God We Trust" na moeda americana, a presença de invocaçôes religiosas no juramento de posse para diversos cargos americanos, muitas vezes realizadas sobre a bíblia, e invocaçóes religiosas em cortes e no congresso, antes do início dos trabalhos (KURU, 2007, p. 571).

Kuru (2007, p. 572) define secularismo passivo como a situação em que o Estado deve tomar uma posição passiva, porém permite a visibilidade pública da religião. Já o secularismo assertivo, em contraste, significa que o Estado exclui a religião da esfera pública e pratica um papel "assertivo" como agente do projeto de engenharia social que confina religião ao domínio privado. Assim, conclui, o secularismo passivo é um princípio político pragmático de neutralidade, enquanto o assertivo é ativamente busca eliminar religião da esfera pública.

O conceito de eliminar a religião da esfera pública é bastante genérico, e merece ser melhor especificado. Como se observa nas diferenças entre a atitude dos 3 países quantos aos 
quesitos apresentados, que variam desde o Estado náo liderar orações mas permitir que sejam feitas pelos próprios alunos, como no caso dos EUA, até o Estado controlar a religião dentro da educação, na Turquia e a "total" proibição de símbolos religiosos nas dependências de escolas pública, mesmo utilizados por alunos, na França. No caso, esfera pública significaria qualquer espaço público gerido pelo Estado, mesmo que a manifestação seja particular e confinada. Essa posição, conforme Blancarte, estaria alinhada com a ideia do laicismo, e não da laicidade ou secularidade (BLANCARTE, 2008, p. 140).

Mesmo a atitude de laicidade passiva dos EUA não existe de forma tão simples. A necessidade de jurar sobre a bíblia para tomar posse em vários cargos públicos é frequentemente questionada. É permito o ato de afirmar, ao invés de jurar, sem o uso de símbolos religioso (conhecido como Quaker legacy ou Quaker exception com origem na lei inglesa (British History Online, 1820 p. 152). São também frequentes os casos de tentativas de leis que tentam inserir conteúdo religioso em aulas ${ }^{8}$ de ciências, ou de forçar manifestaçóes religiosas em espaços públicos.

No Brasil, o problema se torna mais amplo. Quanto à liberdade de consciência, não há interferência, e qualquer um dos modelos de secularidade, passiva ou assertiva, não é prejudicial. Já a questão da liberdade de crença e de culto pode ser afetada, especialmente pelo modelo assertivo. Como ensina Bernardo Fernandes, a liberdade de crença é o direito de um indivíduo adotar uma ou nenhuma religião, o que inclui até mesmo o direito à pratica do proselitismo, enquanto a liberdade de crença, direito individual ou coletivo, está ligado à prática de atos externos de louvação (FERNANDES, 2017, p. 444).

Surge aqui a separação entre os atos do Estado e os atos do indivíduo. Quando o Estado impede que o indivíduo, em sua esfera individual, ainda que em espaço público, pratique atos externos de louvação, como exibir símbolos religiosos, tal ação assertiva extrapola a esfera pública e entra na esfera do privado, o que caracterizar o laicismo, e não a laicidade.

Em contrapartida, um Estado que adota uma posição totalmente neutra, a pura secularidade passiva, também poderá resultar em graves danos aos direitos e liberdades individuais. Cita-se o já observado caso dos crucifixos em tribunais, julgado pelo CNJ e analisado anteriormente, onde pode ser observada claramente a prática da secularidade passiva,

7 Um total que não é total, pois ao passo que símbolos de outras religiōes são totalmente banidos, no caso da religião católica, somente símbolos muito grandes são.

8 e.g.: O Comitê de Educação do Senado do Estado de Idaho aprovou a medida introduzida em uma lei que permitiria aos professores utilizar a Bíblia, para propósito de referência, em aulas como astronomia, geologia e geologia. Do projeto de lei 1321 do Senado: "The Bible is expressly permitted to be used in Idaho public schools for reference purposes to further the study of literature, comparative religion, English and foreign languages, United States and world history, comparative government, law, philosophy, ethics, astronomy, biology, geology, world geography, archaeology, music, sociology, and other topics of study where an understanding of the Bible may be useful or relevant. No student will be required to use any religious texts for reference purposes if the student or parents of the student object."(STONE, 2017). 
fundamentando ainda na tradição, argumento este totalmente inaceitável, pois tendo em vista a perpetuação de distorçôes históricas e ofensa a minorias?.

Jónatas Machado (2002, p. 150) colabora para a discussão, ao afirmar que:

O direito à liberdade religiosa é entendido num sentido amplo, susceptível de garantir a maior medida de proteção ao maior número de indivíduos e grupos compatível com a garantia do mesmo conjunto de liberdades a todos os indivíduos considerados como livres e iguais.

$[\ldots]$

Do mesmo modo, o programa normativo do direito à liberdade religiosa deve ser interpretado de forma extensiva, de forma a proteger todas as manifestaçóes, experiências, vivências, actividades e comportamentos religiosamente motivados, individuais e colectivos, públicos e privados, sem prejuízo da necessária salvaguarda dos direitos de todos os indivíduos e dos bens fundamentais da comunidade e do Estado. O direito à liberdade religiosa deve ser objecto de uma interpretação sistemática, no sentido jurídico, que proteja as dimensóes pessoais e institucionais da vivência religiosa, como a expressão, a informação, a comunicação social, o ensino, a circulação de nacionais e estrangeiros ligados a uma confissão religiosa, a reunião, a manifestação, a associação, a assistência social, a cultura, etc.

Prossegue, então, para traçar os objetivos que devem ser garantidos pela separação das confissóes religiosas do Estado:

1) reforçar no plano institucional a igual dignidade e liberdade de todos os indivíduos, crentes e não crentes; 2) proteger as confissóes religiosas maioritárias e minoritárias de interferências estaduais na sua reserva de autodefinição, autodeterminação e autoorganização. Já aqui foram referidas, por exemplo, as intervenções do Estado na Igreja Católica nomeadamente através do Beneplácito Régio. Esse é o tipo de intervençóes que o princípio de separação visa evitar. Este pretende ainda: 3) proteger as confissóes religiosas minoritárias de uma coligação entre a confissão religiosa maioritária e o Estado através da qual se pretenda instrumentalizar indevidamente o aparelho regulatório estadual para dar maior rigidez e globalidade à posição dominante daquela, enfraquecendo a posição das confissōes minoritárias que com ela se encontram numa situação de confrontação espiritual; 4) salvaguardar a autonomia e a igualdade dos indivíduos e dos grupos não religiosos perante as instituiçóes religiosas, sendo certo que também entre aqueles e estas se verifica uma situação de confrontação espiritual por exemplo em questōes como o aborto, os direitos das mulheres, os direitos dos homossexuais, etc. O princípio da separação visa também: 5) minimizar a conflitualidade social e política com base em motivaçóes religiosas; 6) prevenir o envolvimento excessivo dos poderes públicos com as confissóes religiosas; 7) e 8) garantir a existência de uma esfera de discurso público robusta, desinibida, aberta, em que todas as doutrinas, mundividências, epistemas, ideias, opiniôes e instituiçôes possam ser alvo de discussáo num contexto de interacçáo crítica permanente (MACHADO, 2002, p. 151).

9 Conforme discutido no capítulo anterior. 
Alerta, por último, que do ponto de vista do direito internacional, privilégios concedidos por Estados à uma confissão religiosa são a maior causa de violaçôes de direitos fundamentais a nível internacional.

A posição de Jónatas Machado reflete, e melhor se adequa, de maneira muito mais próxima a realidade da constituição brasileira. Apresenta o dever de laicidade como não apenas um direito contra a interferência do próprio Estado (neutralidade, secularismo passivo), mas também como uma garantia de que o Estado deve atuar positivamente para realizar, em algo que poderia ser chamado, na falta de uma nomenclatura prévia, de secularidade garantista. Passa, assim, ser o dever do Estado atuar passivamente e ativamente. Essencialmente, de forma passiva na esfera pública (não fazendo), e ativamente na esfera privada ou quando a esfera pública interfere na esfera privada, visando ativamente garantir um direito fundamental.

Dworkin oferece mecanismos para análise dos modelos propostos. Inicialmente, não há de se julgar a presença de uma única resposta universal para a questão, vez se tratarem de universos jurisdicionais distintos. $\mathrm{O}$ modelo de secularismo passivo norte-americano, especialmente considerando-se decisóes judiciais que permitem, por exemplo, alunos não recitar o Pledge of Allegiance, ou autoridades e até testemunhas em processos judiciais afirmarem, e não jurarem, apenas refletem a correta aplicação dos princípios, baseados na moralidade política, para, dentro da ideia da integridade, buscar o melhor direito. E, para os Estados Unidos, a base máxima, tanto do ponto de vista legal (conectado ao passado) como da moralidade política (voltada ao futuro) é encontrada na Constituição e no seu típico liberalismo político. A expansão da liberdade individual em face ao Estado, que deve restar neutro, é, assim, não apenas possível mas desejado, dentro da aplicação da hermenêutica política dworkiana ao modelo de secularismo americano.

A análise pela hermenêutica política de Dworkin do secularismo assertivo francês e turco, entretanto, se prova tarefa mais complexa e excessiva para o presente, fazendo-se necessário a realização de um corte epistêmico. Já da realidade brasileira, é justificada e necessária.

As regras positivadas quanto à laicidade brasileira são simples, consistindo essencialmente de 1 norma constitucional expressa no artigo 19, I. Claramente, vedam a opção francesa de financiamento estatal de escolas privadas religiosa. Quanto às demais opçóes dos modelos seculares apresentados, deve-se recorrer a principiologia derivada da moralidade política do Estado Brasileiro. A constituição, declarando a dignidade da pessoa humana como fundamento da república, a não discriminação como objetivo fundamental, além dos direitos e garantias individuais de liberdade de crença e culto, oferecem a direção da moralidade política que aponta para o melhor direito.

Ao mesmo passo, Dworkin nos apresenta questáo importante sobre a diferença de atuação (e alcance) do governo e do cidadão privado. Advoga por uma interpretação igualitária, e não utilitária, e designa papéis. A legislatura tem a obrigação e oportunidade de melhorar a distribuição das leis que cria e responsabilidades que o cidadão privado não possui, além dos meios e estratégias para implementá-las. O governo deve constantemente pesquisar e alterar suas 
regras, ainda que de maneiras radicais, de maneira a torná-las as mais próximas possíveis de tratar todas a pessoas com igualdade nas melhores condiçôes (DWORKIN, 1986, p. 309-310).

As duas posiçôes distintas, do cidadão privado e do Estado, também em nada conflitam, independente do espaço físico em que as interaçôes ocorram. Um magistrado em sua corte não é um cidadão privado, mas uma representação do Estado, como deixa claro o artigo 92 da Constituiçáo Federal. Muito menos pode ser considerada a sala da corte como um espaço privado do magistrado. O magistrado e o espaço são o Estado, e devem se valer pelas normas do mesmo, quaisquer que sejam. Se é permito ao Estado realizar manifestaçóes religiosas, ao magistrado o será. Se não, é vedado. Isto em nada impede, para Dworkin (que separa o cidadão privado do Estado em seus direitos e obrigaçôes) que um magistrado, em seu gabinete particular, tenha alguma iconografia religiosa que o traga conforto, pois nesse espaço o público e o privado se misturam, da mesma forma que seria uma violaçáo de seus direitos pessoais proibir um portaretratos de seus familiares. Permitir o último e vedar o primeiro seria uma violaçáo discriminatória de cunho especificamente religioso. Como corolário, poucos defenderiam o magistrado que, em sala de audiências, tem uma pintura de seus familiares fixada na parede.

Em qualquer coisa, os argumentos teológicos devem ser descartados, seja para vedação de símbolos religiosos na esfera particular do indivíduo (uso por estudante, na França, ou no gabinete particular, no exemplo anterior), seja para a afixação e uso em exercício do Estado (um crucifixo em uma sala de audiências, ou uma manifestação religiosa de um juiz em uma sentença). Isto pois, vez que a Constituição estabelece a laicidade, argumentos doutrinários de natureza religiosa não têm validade jurídica (DWORKIN, 2009, p. 151), sem que isso afete as convicçóes espirituais dos indivíduos envolvidos, pois as restriçôes legais limitam o Estado, e não a liberdade pessoal (DWORKIN, 2005, p. 157).

\section{Consideraçóes finais}

O sagrado é algo tão intrínseco do imaginário e linguajar que, de certa forma não intencional porém irônica, o Ministro Celso de Mello, ao proferir seu voto nos autos da Ação Direta de Inconstitucionalidade 4439, afirma que é na República que está o marco "consagrador" do princípio da laicidade. A laicidade é um princípio tornado sagrado (consagrado).

Presentemente, buscou-se identificar o significado do sagrado e sua compatibilidade com o Estado brasileiro. Em particular, sobre o seu uso em espaços públicos e a forma como está integrado na iconografia (extraoficial) do Estado.

Inicialmente o sentido do sagrado foi delineado, utilizando-se como referência a obra de Dworkin. Como desdobramento do sagrado, em anteposição, definiu-se também o profano. Separou-se o sagrado-religioso do sagrado-secular, este último com uma origem na associaçáo. Rompeu-se com a ideia de sacralidade ontológica, compreendendo-se que o sagrado é uma definição, algo atribuído, porém por uma simples ação de vontade, mas sim em uma construção 
associativa social. O sagrado não é, então, nem extraído na relação objeto-sujeito, nem imposto na relação sujeito-objeto, mas sim algo construído (sua atribuição) intersubjetivamente. Assim, um sagrado não-religioso não apenas se torna possível, como se compreende como parte integrante à própria ideia de Estado, sem qualquer relação (obrigatória) com a laicidade.

O sagrado-religioso é algo associado a cada religiāo, individualmente. Apesar do sincretismo (mistura, etc) causar uma sobreposição, nenhum símbolo sagrado esta presente em todas as religião. Dizendo de outra forma: não existe nenhum objeto ou símbolo sagrado que seja obrigatório para algo ser religiáo. A ideia do sagrado é geral para todas as religióes (de uma forma ou outra), mas o que é sagrado para uma não é, necessariamente, sagrado para nenhuma outra, podendo até mesmo ser profano. Respeitar ostensivamente os preceitos (práticas, crenças) de uma determinada religião pode se tornar uma violação de outra.

Estudou-se, por último, os modelos de laicidade de diversos Estados, com particular atenção aos modelos estadunidense, francês e turco, observando como esses modelos se adequariam ou não à moralidade política brasileira enquanto expressa no texto constitucional. Tal estudo foi destilado, ainda, com a análise de julgados do Conselho Nacional de Justiça, interpretados sob a leitura de Ronald Dworkin.

A observação final é que a aplicação de qualquer modelo importado de laicidade seria incompatível com a ordem constitucional pátria. O sentido da laicidade deve ser algo que seja válido não universalmente, mas para o Brasil. Dworkin permite um diagnóstico do problema, porém não traz a resposta. É necessária uma construção teórica do que é a laicidade no Brasil e, mais do que isso, no Brasil contemporâneo. A laicidade enquanto ser-no-mundo, em um determinado tempo e um determinado lugar. E, só assim, encontrar uma resposta adequada tanto à sociedade brasileira (construída historicamente) e à Constituição. Enquanto o presente trabalho não oferece resposta, faz-se um diagnóstico de tal necessidade, que se torna mais clara.

\section{Referências}

BARBOSA, Rodrigo P. Laicidade e Hermenêutica: compreendendo o estado laico no Brasil contemporâneo em busca de uma resposta adequada à constituição. Belo Horizonte: Dialética, 2020.

BITENCOURT, Cezar Roberto. Código penal comentado. 7. ed. São Paulo: Saraiva, 2012. ebook.

BLANCARTE, Roberto. Laicidad y laicismo en América Latina. Estudos

Sociológicos, El Colegio de Mexico. v. 26 n. 76 p.139-164, jan./apr. 2008.

BLANCARTE, Roberto. ¿Cómo podemos medir la laicidad? Estudos Sociológicos. El Colegio de Mexico. v. 30 n. 88 p. 233-247, jan/apr, 2012. 
BRASIL. Conselho Nacional de Justiça. Pedido de Providência. PP 1344. Rel. Paulo Lôbo. Jul.: 06/06/2007. Disponível em: <http://www.cnj.jus.br/InfojurisI2/ Jurisprudencia.seam?jurisprudenciaIdJuris=45629>. Acesso em: 31 jul. 2017.

BRASIL. Lei de 16 de dezembro de 1830. Manda executar o Codigo Criminal. Disponível em: <http://www.planalto.gov.br/ccivil_03/leis/lim/LIM-16-12-1830.htm>. Acesso em: 31 jul. 2017.

BRASIL. Decreto-Lei n ${ }^{\circ}$ 2.848, de 7 de dezembro de 1940. Código Penal. Disponível em: <http://www.planalto.gov.br/ccivil_03/decreto-lei/Del2848compilado.htm>. Acesso em: 30 jul. 2017.

BRASIL. Lei $n^{\circ} 5.700$, de $1^{\circ}$ de setembro de 1971 . Dispóe sobre a forma e a apresentaçáo dos Símbolos Nacionais, e dá outras providências. Disponível em: <http://www.planalto.gov.br/ccivil_03/leis/L5700.htm>. Acesso em: 31 jul. 2017.

BRASIL. Constituição da República Federativa do Brasil de 1988. Disponível em: <http://www.planalto.gov.br/ccivil_03/constituicao/ConstituicaoCompilado.htm>. Acesso em: 31 jul. 2017.

BRASIL. Decreto $n^{\circ} 678$, de 6 de novembro de 1992. Promulga a Convençáo Americana sobre Direitos Humanos (Pacto de Sáo José da Costa Rica), de 22 de novembro de 1969. Disponível em: <http://www.planalto.gov.br/ccivil_03/decreto/ d0678.htm>. Acesso em: 1 ago. 2017.

BRASIL. Senado Federal. Codigo Philippino, ou, Ordenaçóes e leis do Reino de Portugal: recopiladas por mandado d'El-Rey D. Philippe I. Disponível em: <http:// www2.senado.leg.br/bdsf/item/id/242733>. Acesso em: 31 jul. 2017.

BRASIL. Universidade de São Paulo. Biblioteca Virtual de Direitos Humanos. Declaraçáo Universal dos Direitos Humanos. Disponível em: <http://www. direitoshumanos.usp.br/index.php/Declara\%C3\%A7\%C3\%A3o-Universal-dosDireitos-Humanos/declaracao-universal-dos-direitos-humanos.html>. Acesso em: 1 ago. 2017.

British History Online. William III, 1695-6: An Act that the Solemne Affirmation \& Declaration of the People called Quakers shall be accepted instead of an Oath in the usual Forme. [Chapter XXXIV. Rot. Parl. $7 \& 8$ Gul. III. p.9. n.3.] In: Statutes of the Realm: Volume 7, 1695-1701, ed. John Raithby (s.l, 1820), p. 152. Disponível em: <http://www.british-history.ac.uk/statutes-realm/vol7/p152>. Acesso em: 2 out. 2017.

BUSATO, Paulo César. Direito penal: parte especial 2. 3. Ed. São Paulo: Atlas, 2017. ebook.

DWORKIN, Ronald. Law's Empire. Cambridge: Belknap, 1986; 
DWORKIN, Ronald. A Virtude Soberana: a teoria e a prática da igualdade. Trad. Jussara Simóes. São Paulo: Martins Fontes, 2005.

DWORKIN, Ronald. Levando os Direitos a Sério. São Paulo: Martins Fontes, 2007.

DWORKIN, Ronald. Domínio da Vida: aborto, eutanásia e liberdades individuais. Trad. Jefferson Luiz Camargo. 2. ed. São Paulo: WMF Martins Fontes, 2009.

FERNANDES, Bernardo Gonçalves. Curso de Direito Constitucional. 9. ed. rev., ampl. e atual. Salvador: Juspodivm, 2017.

HUNGRIA, Nelson. Comentários ao Código Penal: volume VIII - arts. 197 a 249. 5. ed. Rio de Janeiro: Forense, 1981.

KURU, Ahmet T. Passive and Assertive Secularism: Historical Conditions, Ideological Struggles, and State Policies toward Religion. World Politics. Cambridge University Press, v. 59, n. 4, jul, p. 568-594, 2007.

MACHADO, Jónatas. A liberdade religiosa na perspectiva dos direitos fundamentais.

Revista Portuguesa de Ciência das Religióes. Universidade Lusófona de Humanidades e Tecnologias, ano I, n. 1, p. 149-154, 2002.

MICHAELIS. Dicionário de Língua Portuguesa. Editora Melhoramentos. Disponível em: $<$ http://michaelis.uol.com.br/busca? $\mathrm{r}=0 \& \mathrm{f}=\& \mathrm{t}=\&$ palavra=sagrado $>$. Acesso em: 30 jul. 2017.

SIMIONI, Rafael Lazzarotto. Curso de Hermenêutica Jurídica Contemporânea: do positivismo clássico ao pós-positivismo jurídico. Curitiba: Juruá, 2014.

STONE, Michael. Idaho Bill Allows Teachers To Use Bible As Science Textbook. Disponível em: <http:/www.patheos.com/blogs/progressivesecularhumanist/2016/02/ idaho-bill-allows-teachers-to-use-bible-as-science-textbook/>. Acesso em: 2 out. 2017. 